$\mathrm{kg}$ of high explosives. John Shaner, who directs several collaborative projects between the two laboratories, says that they are not at present trying to achieve fusion, but may do so in the future.

In a paper released this month by the Federation of American Scientists, Frank von Hippel says that the laboratories have been pushing for an interpretation of the test ban treaty that would exempt research, development and test of pure fusion devices. Hippel served the Clinton administration as associate director for national security in the Office of Science and Technology Policy.

Last week, von Hippel was in Moscow and unavailable for comment. But a spokesman for Livermore said: "We have technical discussions with the Department of Energy and let them decide what to push for and what not to push for. It is not a Livermore function to make policy."

In testimony to the Congress last year, however, Paul Robinson, the director of the third US weapons laboratory, at Sandia in New Mexico, told the Senate Armed Services Committee that the laboratories needed to employ "various approaches to inertial confinement fusion" to maintain US weapons without testing.

Robinson wants an exemption for Sandia's efforts to achieve fusion by powerpulse-driven X-rays. Chris Paine, an analyst at the Natural Resources Defence Council, says that the other laboratories want exemption for fusion from high explosives.

Weapons experts remain divided on the feasibility of pure fusion weapons. Sidney Drell, deputy director of the Stanford Linear Accelerator Center in California and a regular adviser to the federal government on nuclear questions, doubts that such a weapon would ever work.

"There's a range of views on this, but I don't care if we allow an exemption, as long as we get the test ban treaty [ratified]." $\mathrm{He}$ says that, even if some scientists in the laboratories are keen to pursue the weapons, the management at the laboratories has no interest in doing so.

But some scientists say that pure fusion weapons could work. Sam Cohen, who worked with Bethe on the Manhattan Project, and is now an ardent defence 'hawk', contends that Russia already has them - a claim hotly denied by official US sources.

Cohen wants the United States to end its unclassified collaboration with Russia and get on with developing what he calls "the most useful battlefield weapons ever devised".

Ted Taylor, a former weapons designer at Los Alamos who has opposed nuclear weapons for 30 years, says he "applauds Bethe's position". But he says that the National Ignition Facility - which Bethe and Kidder support - will contribute to the eventual development of pure fusion weapons.

ColinMacilwain

\section{Congressional critic backs amended deal on collider}

[WASHINGTON] A modified agreement for US participation in the Large Hadron Collider project at the European Laboratory for Particle Physics (CERN) has been accepted by James Sensenbrenner (Republican, Wisconsin), chairman of the Science Committee in the House of Representatives, who had previously expressed reservations about the deal.

The modifications will now go to the CERN council in Geneva, Switzerland, for ratification. But Sensenbrenner warns that opposition remains strong in the Congress to a proposal that the United States should contribute to the collider's construction costs (see Nature 387, 3; 1997). He predicts that the proposal could face defeat unless the Clinton administration works harder to back it.

The modified deal was negotiated by CERN and the US Department of Energy in response to Sensenbrenner's concerns. It is believed to be similar in substance to the one initialled in February by Martha Krebs, assistant energy secretary, and Christopher Llewellyn Smith, director-general of CERN.

The modifications include a pledge in the introduction to the agreement that CERN member states will consider, in good faith, participation in future international particle physics projects. Cash amounts in the agreement are now prefixed with the phrase "not to exceed", and management arrangements are more clearly spelt out. For example, it is stated that the United States will be immediately informed if the machine is not going to meet certain specified performance targets.

Officials on both sides of the Atlantic are quietly confident that the new deal will be accepted by the CERN council when it meets on 20 June. Federico Peña, the US energy secretary, said: "I believe we now have an amended and significantly strengthened agreement which, when ratified and signed, will better protect the interests of the United States." A spokesman for CERN said that Sensenbrenner "has done a good job" in clarifying specific points of the agreement.

Sensenbrenner said that, if the deal is ratified by the CERN council, he would propose an amendment to next year's US budget to restore $\$ 35$ million for work related to the collider project which had previously been deleted by his committee.

But he said that he was "very disappointed that there has been no leadership from the energy department, the White House Office of Science and Technology Policy or the president" on justifying US participation in the project's construction. "Unless they hit a double, an amendment to restore that funding would be defeated." In baseball, a double is a good hit, rather like a four in cricket.

Funding for the collider project will now be considered by other committees in the Congress before they agree a 1998 budget in the autumn. Last week, nine US Nobel prizewinners in physics wrote to congressional leaders expressing support for participation in the project.

C.M.

\section{Nest of mirrors promises X-ray relief}

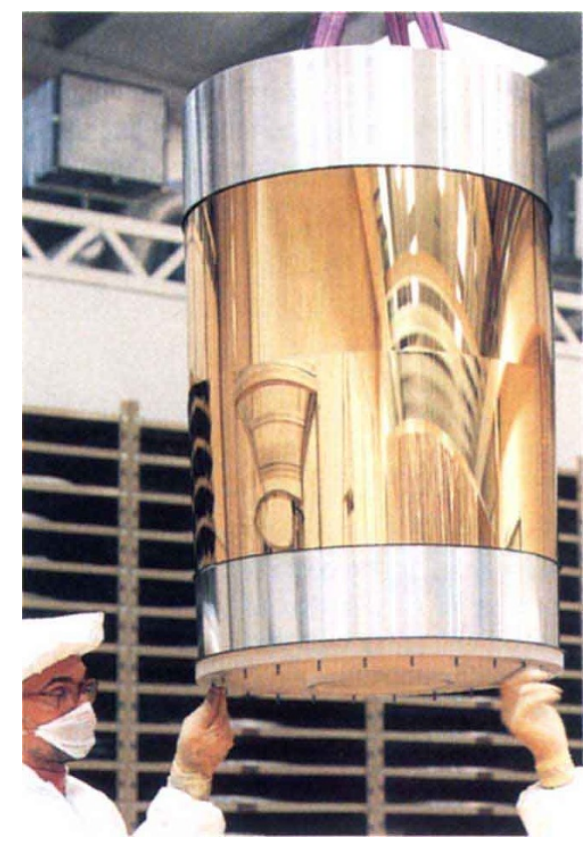

[MUNICH] Fifty-eight gold-plated X-ray mirrors nested together in shells, and separated by a distance of only $1-4 \mathrm{~mm}$, form the telescopes on the European Space Agency's next cornerstone mission, an X-ray satellite known as XMM (see left). This unique technology gives XMM the largest Xray collecting area of any currently planned $\mathrm{X}$-ray mission.

$\mathrm{XMM}$ is also unique in carrying a sensitive optical telescope that will allow it to follow up $\mathrm{X}$-ray observations in the optical range immediately. Scientists observing the X-ray 'afterglow' of shortacting gamma-ray bursts will no longer have to rely exclusively on ground-based telescopes to help identify their sources.

Tensions within the astrophysics community about access to ground-based telescopes were palpable after recent observations of gamma-ray bursts by the Italian satellite Beppo-SAX. XMM is due to be launched in August 1999. 